\title{
A Perspective on Possible Fed Exit Strategies
}

\author{
Daniel L. Thornton, Vice President and Economic Adviser
}

I

$t$ is widely recognized that the current low interest rate environment is not sustainable. As the economy expands and interest rates rise, banks will have an incentive to transform their massive holdings of excess reserves into required reserves by making loans or investments and the money supply will expand correspondingly. The Federal Reserve has three basic options to prevent an unacceptably large expansion of the money supply: increasing reserve requirements, paying interest on excess reserves (IOER), ${ }^{1}$ or selling securities. Payment of IOER has received the most attention and appears to be the preferred option among policymakers. This essay discusses several problems associated with paying IOER and raising reserve requirements and suggests that the best strategy is selling securities and returning the Fed's portfolio to its historical structure.

\section{Increasing Reserve Requirements}

Raising reserve requirements to their statutory limits22 percent on transactions deposits and 6 percent on nontransactions deposits-cannot work because doing so would not impound a sufficiently large quantity of excess reserves. This problem is further complicated by the fact that, since late 1994, depository institutions have been reducing their effective reserve requirements by "sweeping" their transactions deposits into deposits not subject to reserve requirements. ${ }^{2}$ For this strategy to be effective, the Federal Reserve Act would have to be amended to increase the statutory limit on reserve requirements to near 100 percent.

\section{Paying Interest on Excess Reserves}

The IOER strategy can work. However, I foresee several potential difficulties associated with payment of IOER that render its use questionable as either a transition strategy (shrinking the Fed's portfolio to levels consistent with returning to targeting the funds rate) or a long-run strategy (using IOER to target short-term interest rates while permanently maintaining a large balance sheet). Important among these difficulties is that the interest rate paid on excess reserves will have to equal the marginal risk-adjusted bank lending rate. This means the excess income over operating expenses-which the Fed transfers to the Treasury ( $\$ 88.9$ billion in 2012), and hence reduces the federal deficit-will instead be paid to depository institutions. As the IOER rate increases, less money will be given to the Treasury and more will be given to banks for the sole purpose of holding excess reserves (i.e., idle deposits at Federal Reserve Banks). Congress is likely to be unhappy with this outcome because it will increase the deficit. Of course, the deficit would also increase if the Fed sold securities to return the balance sheet to normal because the Fed's interest income would decline.

Regardless of which option the Fed chooses, perceptions are important. The perception of IOER payments is likely to be somewhat different because the funds will be paid to banks. Concern could be intensified because most excess reserves are held by large institutions, the majority of which are foreign owned. The public's perception of large IOER payments to banks is likely to be jaundiced because many believe such institutions were responsible for the financial crisis and accompanying recession.

\section{As the IOER rate increases, less money will be given to the Treasury and more will be given to banks for the sole purpose of holding excess reserves (i.e., idle deposits at Federal Reserve Banks).}

Moreover, I believe that paying IOER might be more difficult to implement than most analysts suggest. The banking system is not homogeneous. Institutions have different investment strategies and opportunities. Consequently, the risk-adjusted lending rates across institutions are likely to vary somewhat (perhaps considerably). As a result, a one-rate-fits-all approach could provide a significant subsidy to some institutions, while failing to lock up the excess reserves of others. Of course, the Fed could have a structure of IOER rates that varied across institutions. 
This might be problematic because determining a particular institution's risk-adjusted lending rate is likely to be difficult. The one-rate-fits-all approach is much easier to administer because the Fed would need only to set the rate at a level sufficiently high to stem the outflow from excess reserves.

Two other concerns are more subtle. First, the purpose of paying IOER is to allow interest rates to rise while maintaining a large portfolio of mortgage-backed securities (MBS) and long-term agency and government debt. The primary motivation for holding a large amount of longterm debt was to alter the maturity structure of the public's holdings of debt and, thus, affect long-term yields. However, the public's holdings of long-term Treasuries and MBS will increase over time. Hence, the FOMC will be unable to alter the maturity structure of the public debt in the future without expanding the size of the Fed's portfolio. Maintaining a large portfolio of long-term debt will not be sufficient.

Second, it is important to note that a small reduction in excess reserves can generate a relatively large change in the money supply. For example, if the effective reserve requirement were 10 percent, the M1 money supply, currently about $\$ 2.5$ trillion, could increase by 20 percent with only a $\$ 25$ billion (1.3 percent) reduction in excess reserves. Consequently, the IOER rate will have to be adjusted quickly as lending rates rise. The nearly simultaneous rise in the lending rate and the IOER rate (which is an administered rate, not a market rate) will undoubtedly cause some analysts to conclude that the FOMC-not the credit marketcaused lending rates to increase. Hence, there is likely to be considerable pressure to maintain the IOER rate as lending rates rise and money growth accelerates.

\section{Selling Securities}

For all the reasons noted, I believe the best exit strategy is to reduce the Fed's portfolio to a level that will allow the FOMC to return to its practice of interest rate targeting used prior to the Lehman Brothers bankruptcy in midSeptember 2008. This strategy could be accomplished either through outright sales or by continuously rolling over reverse repurchase agreements. The effect on the balance sheet is the same regardless of the method used. However, the FOMC might use a combination of reverse repurchase agreements and outright sales as was commonly done to expand the balance sheet to meet the needs of a growing economy.

The downside of this strategy is that bond prices fall as interest rates rise. Hence, the Fed could suffer a capital loss-that is, receive a lower price for the securities when they are sold than when they were purchased. The possibility of the Fed suffering significant capital losses is mitigated by the fact that many of the securities were purchased when bond prices were much lower (i.e., bond yields were much higher). This means interest rates would have to rise somewhat before any capital loss on such bonds would be incurred. The likelihood of significant capital losses could also be reduced by selling longer-term securities and simultaneously purchasing short-term securities in advance of reducing the overall size of the Fed's balance sheet.

\footnotetext{
Notes

1 Term deposits and reverse repurchase agreements are two other options. However, they do effectively the same thing as paying IOER. The Fed pays interest to banks to "lock up" reserves.

2 See Anderson, Richard G. and Rasche, Robert H. "Retail Sweep Programs and Bank Reserves, 1994-1999.” Federal Reserve Bank of St. Louis Review, January/ February 2001, 83(1), pp. 51-72;

http://research.stlouisfed.org/publications/review/01/0101ra.pdf.
} 